УДК 631.51:631.81:632.51

(C) 2018

Ткачук В. П., кандидат сільськогосподарських наук

Інститут сільського господарства Полісся НААН

\author{
Саюк О. А., Плотницька Н. М., Гурманчук О. В., кандидати сільськогосподарських наук, \\ Павлюк I. O., аспірант \\ (науковий керівник - кандидат сільськогосподарських наук О. А. Саюк) \\ Житомирський національний агроекологічний університет
}

\title{
ВПЛИВ СПОСОБІВ ОСНОВНОГО ОБРОБІТКУ ГРУНТУ ТА СИСТЕМ УДОБРЕННЯ НА ЗАБУР'ЯНЕНІСТЬ ПОСІВІВ ПОЛЬОВИХ КУЛЬТУР
}

\section{Рецензент - доктор сільськогосподарських наук, професор В. Б. Ковальов}

\begin{abstract}
Наведено дані щеодо впливу способів основного обробітку трунту та систем удобрення на забур'яненість посівів польових культур. Встановлено, що систематичне проведення впродовж чотирьох ротацій дев'ятипільної сівозміни дискового та плоскорізного обробітків призводить до збільшення потенційної забур'яненості трунту на 22-50\%, порівняно зі щорічною оранкою. Використання органомінеральної та органічної систем удобрення призводить до збільшення чисельності бур'янів у шарі 0-20 см у 1,2-1,5 рази, порівняно з неудобреним фоном. Фактична забур'яненість агроченозу пшениці озимої на початку вегетації культури при проведенні оранки та дискування за різних систем удобрення становить відповідно 9-18 та 23-42 шт./ $\mathrm{M}^{2}$, тоді як y посівах ярих культур (люпин, льон олійний, кукурудза, картопля) ці показники коливаються в межах 8-92 ma 26-708 $\mathrm{um} . / \mathrm{M}^{2}$.
\end{abstract}

Ключові слова: бур'яни, обробіток трунту, система удобрення, потенційна забур'яненість, фактична забур'яненість, сівозміна.

Постановка проблеми. При вирощуванні сільськогосподарських культур однією із головних проблем, що призводить до зниження урожайності та погіршення якості врожаю, $є$ забур'яненість посівів. Шкідливість бур'янів у посівах культурних рослин є результатом гострої конкуренції за основні фактори життя рослин: світло, воду, поживні речовини. Бур'яни, що розмножуються насінням, мають високий потенціал до відновлення, можуть протягом багатьох років не втрачати своєї життєздатності, що спричиняе значні проблеми у сільському господарстві. Чим вищі запаси насіння та органів вегетативного розмноження бур'янів у грунті, тим більше його проросте за сприятливих умов у майбутньому. Незважаючи на інтенсивне застосування гербіцидів при вирощуванні сільськогосподарських культур, потенційна забур'яненість орного шару не зменшується $[4,6,7]$.

Засмічення полів викликає значні втрати грун- тової вологи: на утворення одного кілограма сухої речовини бур'яни потребують значно більше вологи, ніж культурні рослини; деякі види бур'янів $\epsilon$ резерваторами різних видів шкідників і збудників хвороб сільськогосподарських культур; наявність бур'янів у посівах ускладнює виконання багатьох сільськогосподарських робіт. Популяції бур'янів практично повсюдно присутні в структурі агрофітоценозів, утворюючи в сукупності компонент із специфічним для кожного поля видовим складом та чисельністю окремих видів бур'янів, а також потенційним запасом у грунті їх насіння і органів вегетативного розмноження. Сформувавшись у процесі багатовікової історії землеробства, сучасні популяції бур'янів набули комплексу особливостей, що дозволяють їм протистояти інтенсивному антропогенному впливу $[4,6]$.

Аналіз основних досліджень і публікацій, у яких започатковано розв'язання проблеми. Основними способами контролю чисельності бур'янів у посівах сільськогосподарських культур є система обробітку грунту, дотримання сівозміни, система застосування добрив, хімічні прийоми догляду за посівами. Проте 3 метою якісного контролювання чисельності бур'янів в агрофітоценозах якогось одного прийому не достатньо, їх необхідно застосовувати у комплексі та з урахування типу забур'яненості [6].

Системи обробітку грунту повинні забезпечувати протибур'янову ефективність, підвищувати здатність агрофітоценозів до саморегулювання у напрямку зниження частки бур'янового компоненту. Вони визначають особливості розташування насіння бур'янів та органів їх вегетативного розмноження в орному шарі. Одним із найдавніших агротехнічних способів боротьби з бур'янами $\epsilon$ механічний обробіток грунту. Раціональний обробіток грунту зменшує забур'яненість посівів на 50-60 \% та сприяє підвищенню конкурентоспроможності культурних рослин. Полицевий обробіток грунту 


\section{СІЛЬСЬКЕ ГОСПОДАРСТВО. РОСЛИННИЦТВО}

вважається основним агротехнічним заходом боротьби з бур'янами, оскільки при ньому їх насіння загортається у глибші шари, де потрапляє у несприятливі умови та втрачає свою життєздатність. Дослідженнями встановлено, що дворазове лущення стерні 3 наступною оранкою знижує забур'яненість посівів зернових культур на $32 \%$, картоплі - на 45 \%, порівняно 3 посівами, де проводиться оранка без лущення. Із загальних запасів насіння бур'янів, що міститься у грунті, лише $25 \%$ надовго зберігає схожість, але і їх кількість значно перевищує можливий поріг шкоди $[6,8]$.

У посівах більшості сільськогосподарських культур застосування добрив сприяє підвищенню урожайності та може по-різному впливати на забур'яненість полів, зменшуючи або збільшуючи частку шкідливих бур'янів. Одним із головних джерел забур'янення полів є органічні добрива, що містять життєздатне насіння бур'янів, кількість якого часто сягає декількох мільйонів штук у 1 т гною або компосту. Вплив мінеральних добрив на ріст і розвиток бур'янів у посівах польових культур неоднозначний. В одних випадках відмічається, що при покращенні умов мінерального живлення посилюється забур'яненість посівів, в інших - що на удобрених і провапнованих грунтах темпи росту культурних рослин вищі, порівняно 3 неудобреними, що створює сприятливі умови для них у формуванні конкурентних відносин з бур'янами. Тому питання впливу удобрення на забур'яненість посівів потребують більш детального вивчення, особливо в конкретних грунтово-кліматичних умовах $[5,6,8]$.

Мета досліджень полягала у визначенні впливу обробітків грунту та систем удобрення на забур'яненість посів сільськогосподарських культур.

Основним завданням було дослідження зміни потенційної забур'яненості грунту та особливості формування бур'янової рослинності в агроценозах 9-пільної зерно-просапної сівозміни залежно від тривалого застосування різних способів основного обробітку грунту та систем удобрення.

Матеріали і методи досліджень. Спостереження за факторами динамічної зміни та формування сегетальної рослинності у посівах сільськогосподарських культур, а також аналіз їх впливу на продуктивність агроценозів, проводились у зоні Правобережного Полісся України на дослідному полі Інституту сільського господарства Полісся НААН України (село Грозино Коростенського району) в стаціонарному досліді.

Дослідження проводилися на дерновосередньопідзолистому супіщаному грунті в стаціонарному досліді, закладеному у 1981 році в дев'ятипільній сівозміні, розгорнутій у четвертій ротації на чотирьох полях. В орному шарі (0-20 см) грунту вміст гумусу (за Тюріним) становив 1,19$1,22 \%$, сполук азоту, що легко гідролізуються, 34,5-37,2 мг/кг грунту, рухомих форм фосфору 11,2-16,2, обмінного калію - 10,1-11,7 мг на 100 г грунту, $\mathrm{pH}($ ксl $)-4,9-5,3$.

Дослід закладено методом розщеплених ділянок: на ділянках першого порядку 3 посівною площею 529 м ${ }^{2}$ вивчалися способи обробітку грунту, на ділянках другого порядку з обліковою площею $72 \mathrm{~m}^{2}$ - системи удобрення. Повторність у досліді - триразова.

Аналіз агрометеорологічних умов років проведення досліджень засвідчив, що показники температурного режиму та кількості опадів були в межах норми. Лише вегетаційний період 2016 року характеризувався недостатньою кількістю опадів та запасів доступної вологи в грунті, підвищеним температурним режимом, особливо в критичні періоди росту і розвитку основних сільськогосподарських культур, що негативно вплинуло на ріст, розвиток та формування їх врожаю.

Облік бур'янів у посівах та потенційну забур'яненість грунту визначали за загальноприйнятими методиками, видовий склад бур'янів і їх насіння - за посібниками, ілюстрованими визначниками, гербаріями, колекціями $[1,2]$.

Статистичну обробку отриманих експериментальних даних проводили методом дисперсійного аналізу за допомогою прикладних комп'ютерних програм [3].

Результати досліджень. Відомо, що заходи регулювання контролю бур'янів мають грунтуватися на передбаченні їх чисельності, яка діагностується, в першу чергу, потенційними (прихованими) запасами насіння бур'янів у грунті. Значний вплив на формування потенційної забур'яненості грунту спричиняють способи основного обробітку. У результаті проведення обліку насіння бур'янів у грунті виявлено, що на кінець четвертої ротації 9-пільної зерно-просапної сівозміни потенційна забур'яненість орного шару грунту (0-20 см) є досить високою та залежно від способів основного обробітку грунту і різних рівнів удобрення й знаходиться у межах 1,522,83 млн штук насінин бур'янів на 1 га (рис. 1).

У результаті досліджень встановлено, що систематичне проведення впродовж чотирьох ротацій 9-пільної сівозміни дискового та плоскорізного обробітків призводить до збільшення потенційної забур'яненості грунту на 22-50 \%, порівняно зі щорічною оранкою. 


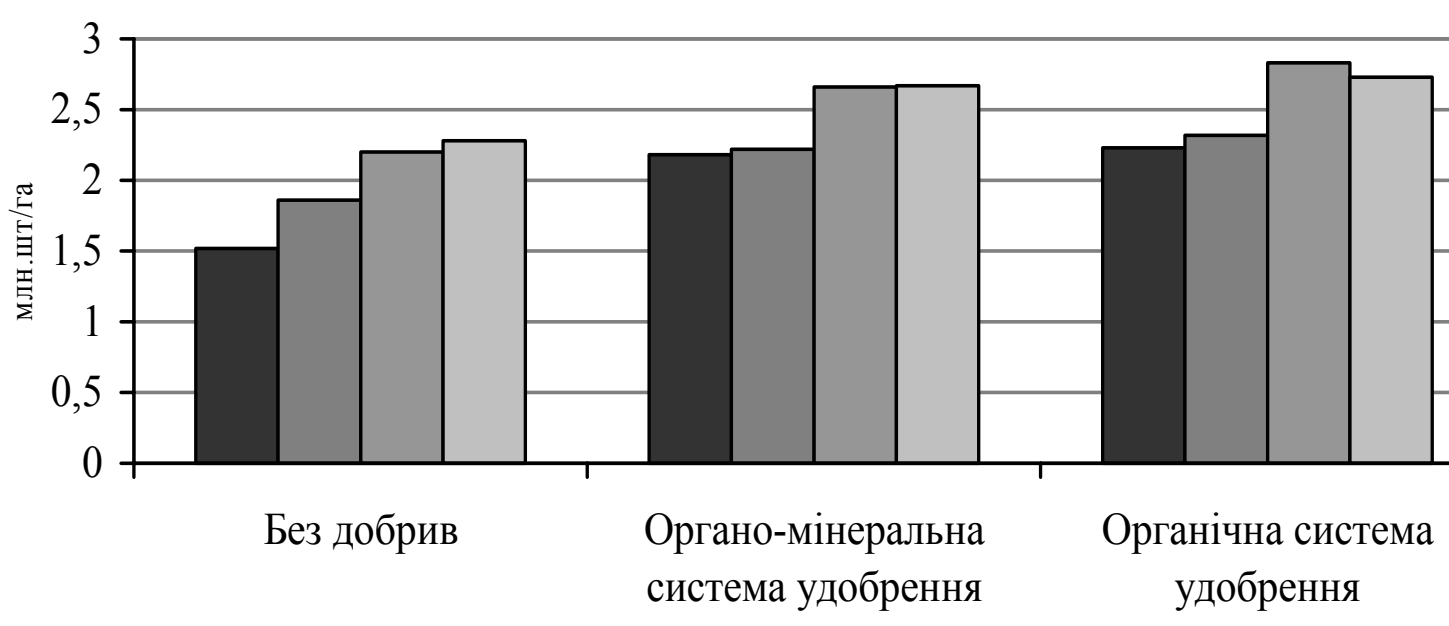

Звичайна оранка, 20-22 см

$\square$ Мілка оранка, $12-14 \mathrm{~cm}$

口Дискування, 10-12 см

口Плоскорізний обробіток, 20-22см

Рис. 1. Вилив способів основного обробітку і систем удобрення на потенційну забур'яненість орного шару дерново-підзолистого супіщаного грунту, млн штук / zа, 2015-2017 pp.

\section{1. Вилив способів основного обробітку трунту на забур'яненість посівів ярих культур} 9-пільної сівозміни, 2015-2017 рр.

\begin{tabular}{|c|c|c|c|c|c|c|}
\hline \multirow{3}{*}{$\begin{array}{l}\text { Спосіб і глибина } \\
\text { обробітку грунту }\end{array}$} & \multicolumn{6}{|c|}{ Кількість бур'янів, штук/м² } \\
\hline & \multicolumn{3}{|c|}{ на початку вегетації } & \multicolumn{3}{|c|}{ перед збиранням } \\
\hline & фон 0 & фон 1 & фон 2 & фон 0 & фон 1 & фон 2 \\
\hline \multicolumn{7}{|c|}{ Люпин (після льону олійного) } \\
\hline Оранка, 18-20 см & 12 & 17 & 22 & 92 & 32 & 68 \\
\hline Дискування, 8-10 см & 59 & 72 & 81 & 396 & 120 & 226 \\
\hline \multicolumn{7}{|c|}{ Льон олійний (після картоплі) } \\
\hline Оранка, 18-20 см & 92 & 87 & 88 & 35 & 28 & 40 \\
\hline Дискування, 8-10 см & 432 & 566 & 708 & 49 & 33 & 38 \\
\hline \multicolumn{7}{|c|}{ Кукурудза (після пшениці озимої) } \\
\hline Оранка, 18-20 см & 8 & 13 & 19 & 43 & 34 & 38 \\
\hline Дискування, 8-10 см & 26 & 42 & 54 & 234 & 185 & 226 \\
\hline \multicolumn{7}{|c|}{ Картопля (після жита озимого) } \\
\hline Оранка, $18-20$ см & 34 & 45 & 47 & 52 & 36 & 46 \\
\hline Дискування, 8-10 см & 43 & 56 & 68 & 124 & 105 & 106 \\
\hline
\end{tabular}

\section{2. Вилив способів основного обробітку трунту на забур'яненість посівів пиениці озимої,} 2015-2017 pp.

\begin{tabular}{|c|c|c|c|c|c|c|c|c|c|}
\hline \multirow{3}{*}{$\begin{array}{l}\text { Спосіб і глибина } \\
\text { обробітку грунту }\end{array}$} & \multicolumn{9}{|c|}{ Кількість бур'янів, штук/м² } \\
\hline & \multicolumn{3}{|c|}{$\begin{array}{c}\text { перед припиненням } \\
\text { вегетації }\end{array}$} & \multicolumn{3}{|c|}{$\begin{array}{c}\text { після відновлення } \\
\text { вегетації } \\
\end{array}$} & \multicolumn{3}{|c|}{$\begin{array}{c}\text { перед } \\
\text { збиранням }\end{array}$} \\
\hline & фон 0 & фон 1 & фон 2 & фон 0 & фон 1 & фон 2 & фон 0 & фон 1 & фон 2 \\
\hline Оран & 9 & 10 & 13 & 11 & 14 & 18 & 25 & 18 & 21 \\
\hline Дискування, 8-10 см & 23 & 31 & 33 & 28 & 39 & 42 & 51 & 32 & 41 \\
\hline
\end{tabular}




\section{СІЛЬСЬКЕ ГОСПОДАРСТВО. РОСЛИННИЦТВО}

Пояснюється це тим, що за способів безполицевого обробітку темпи поповнення насіння бур'янів у грунті, за рахунок новоутвореного, здебільшого переважають над природним i антропогенним його знищенням.

Дослідженнями встановлено, що кількість насіння бур'янів в орному шарі грунту залежить також від систем удобрення. Так, на ділянках із органо-мінеральною та органічною системами удобрення їх чисельність у шарі 0-20 см була вищою в 1,2-1,5 рази, порівняно 3 неудобреним фоном, що пояснюється додатковим внесенням насіння бур'янів у грунт з гноєм та соломою.

Отже, за органічної системи удобрення та проведення дискування на глибину 8-10 см кількість насіння бур'янів в орному шарі грунту становить 2,83 млн штук/га, що перевищує відповідний показник при проведенні оранки на глибину 20-22 см без застосування добрив у 1,9 рази.

Важливим критерієм ефективності способів основного обробітку грунту $є$ рівень фактичної забур'яненості посівів. Зокрема, в агроценозі пшениці озимої на початку вегетації культури при проведенні оранки та дискування за різних систем удобрення проростало бур'янів відповідно 9-18 та 23-42 штук/м², тоді як у посівах ярих культур (люпин, льон олійний, кукурудза, картопля) ці показники коливалися в межах 8-92 та 26-708 штук/м² (табл. 1, 2).

Отже, проведення дискування та внесення органічних добрив сприяє збільшенню фактичної забур'яненості посівів ярих культур на початку їх вегетації культур у 1,4-2,1 раза, порівняно із варіантом без застосування добрив. Перед збиранням урожаю, навпаки, фактична забур'яненість посівів ярих культур у варіантах із неудобреним фоном зростала у 1,0-1,8 раза, по-

\section{БІБЛІОГРАФІЯ}

1. Веселовський I. В. Атлас-визначник бур'янів / І. В. Веселовський, А. К. Лисенко, Ю. П. Манько. К. : Урожай, 1988. - 72 с.

2. Грицаєнко 3. М. Методи біологічних та агрохімічних досліджень рослин i грунтів / 3. М. Грицаєнко, А. О. Грицаєнко, В. П. Карпенко / К. ЗАТ «НІЧЛАВА», - 2003. - 320 с.

3. Доспехов Б. А. Методика полевого опыта (с основами статистической обработки результатов исследований) / Б. А. Доспехов - М. : Колос, 1985. $-352 \mathrm{c}$.

4. Іващценко О. О. Бур'яни в агрофітоценозах. / О. О. Іващенко. - К. : Світ, 2001. - 234 с.

5. Каленська С. М. Структура агроценозів озимого тритикале АДМ 11 і Поліський 7 залежно від рівняно із органічною системою, та у 1,2-3,3 раза, порівняно із органо-мінеральною системами удобрення.

Тривале, впродовж чотирьох ротацій, проведення безполицевого обробітку дисковими знаряддями на глибину 8-10 см призвело до підвищення загальної забур'яненості на початку вегетації в посівах пшениці озимої в 2,5-3,1 рази, люпину вузьколистого - в 3,6-4,9 рази, кукурудзи - в 2,8-3,2 та льону олійного - 4,6-8,0 разів, порівняно 3 оранкою на глибину 18-20 см. На кінець вегетації в посівах пшениці озимої залишилося бур'янів у межах 18-51 штук/м².

Застосування у 9-пільній зерно-просапній сівозміні органо-мінеральної системи удобрення (10 т гною $\mathrm{N}_{45} \mathrm{P}_{60} \mathrm{~K}_{67,5}$ на 1 га сівозмінної площі) сприяло зниженню загального рівня забур'яненості посівів у кінці вегетації пшениці озимої в 1,5 рази, льону олійного - 1,4 рази, люпину вузьколистого та кукурудзи - 3,1 та 1,3 рази відповідно, порівняно 3 неудобреним фоном, за рахунок кращого пригнічення бур'янів культурними рослинами.

Висновки. Таким чином, на підставі отриманих даних можна стверджувати, що в умовах достатнього зволоження зони Полісся система основного обробітку грунту, яка базується на проведенні звичайної оранки на глибину 18$20 \mathrm{~cm}$, має значні переваги у зменшенні забур'яненості посівів перед системою обробітку на засадах безполицевого обробітку дисковими знаряддями. Подальші дослідження будуть спрямовані на детальне вивчення впливу тривалого застосування обробітків грунту та систем удобрення на забур'яненість посівів розширеної зерно-просапної сівозміни.

систем удобрення і захисту / С. М. Каленська // Матеріали 4-ї наук. теорет. конф. гербологів «Проблеми бур'янів і шляхи зниження забур'янення орних земель» - К. : Колобіг. - 2004. - С. 133-139.

6. Манько Ю. П. Бур'яни та заходи боротьби 3 ними/ Ю. П. Манько, І. В. Веселовський, Л. В. Орел, С. П. Танчик - К. : Учбово-методичний центр Мінагропрому України. - 1998. - 240 с.

7. Протопопова В. В. Синатропна флора України / В. В. Протопопова - К. : Наукова думка, 1991. -202 c.

8. Сайко В.Ф. Системи обробітку грунту в Україні / В. Ф. Сайко, А. М. Малієнко. - К. : ВД "ЕKMO", 2007. - 44 c. 